\title{
Duodenal mucosa and extracellular cyclic nucleotide pattern in coeliac disease
}

\author{
M Peracchi, F Bamonti-Catena, P Faggioli, N Molteni, M T Bardella, B Bareggi, P A Bianchi
}

\begin{abstract}
This study measured the values of cyclic nucleotides and adenylate and guanylate cyclase activities in duodenal mucosa homogenates to verify if they played a part in coeliac disease. Nine controls, 13 patients who did not receive treatment and nine patients who received treatment were studied. Cyclase activity assays were performed under basal conditions and in the presence of gliadin derived peptides. Duodenal mucosa cyclic nucleotide values and adenylate cyclase activity were significantly higher in patients who did not receive treatment than in those who did and in controls, whereas guanylate cyclase activity was similar in all groups. Gliadin derived peptides did not affect guanylate cyclase activity, but significantly increased adenylate cyclase activity in homogenates from patients who did not receive treatment. As extracellular cyclic nucleotide concentrations could reflect changes in their intracellular metabolism, plasma and urine cyclic nucleotide values were also measured in 25 controls and in 55 patients studied at different stages of their disease. Extracellular cyclic nucleotides were considerably high in patients who were not healed and became normal after about one year of treatment. These data suggest that cyclic nucleotides may participate in the pathophysiological processes of coeliac disease.
\end{abstract}

(Gut 1993; 34: 769-773)

The biochemical basis for gluten toxicity in coeliac disease is still not known. Preliminary studies have shown that in mucosa from the small intestine of patients with active coeliac disease the activity of adenylate cyclase, a basolateral membrane enzyme which catalyses the synthesis of adenosine $3^{\prime}, 5^{\prime}$-monophosphate (cyclic AMP, cAMP) from adenosine triphosphate (ATP), is abnormally high under basal conditions, ${ }^{12}$ and increases further in the presence of gliadin derived peptides. ${ }^{2}$ The guanylate cyclase-guanosine $3^{\prime}, 5^{\prime}$-monophosphate (cyclic GMP, cGMP) system has not been similarly studied. In intestinal epithelium, cyclic nucleotides are involved in the regulation of water and electrolyte transport and mediate the action of various hormones, prostaglandins, and bacterial enterotoxins. ${ }^{3-6}$ Furthermore, both cAMP and cGMP have been suggested to play a part in proliferative and inflammatory processes, ${ }^{7-9}$ which are known to occur in the small bowel mucosa of patients with coeliac disease.

In this study we measured adenylate and guanylate cyclase activities and cyclic nucleotide values in the biopsy specimens of duodenal mucosa from patients with untreated and treated coeliac disease. Moreover, as extracellular cyclic nucleotide concentrations could reflect changes in their intracellular metabolism, plasma, and urine cyclic nucleotide values were also assessed in a large series of coeliac patients studied at different stages of their disease.

\section{Methods}

\section{PATIENTS}

Fifty five patients with coeliac disease proved by biopsy (13 men and 42 women, aged 18-66, mean $32 \cdot 1)$, were studied. Twenty had a recent diagnosis and were untreated and 35 were in clinical, biochemical, and histological remission after more than one year of gluten free diet. No patient had any concomitant disease. Control groups included 25 normal subjects (seven men and 18 women, aged $18-67$, mean 36.8 ), and nine patients with epigastric pain without any evidence of small bowel disease (three men and six women, aged 24-56, mean 35.8). All subjects gave informed consent for the study, which was approved by the local ethical committee.

\section{BIOPSY SPECIMENS}

Duodenal biopsy specimens were taken during diagnostic endoscopies with biopsy forceps from 13 untreated (mucosa morphology grade III-IV, according to Scott and Losowsky ${ }^{10}$ ) and nine treated coeliac patients (mucosa morphology grade I-II), and from nine patients investigated for epigastric pain (normal villous structure). Biopsy specimens were processed immediately. Some specimens were insufficient to check either cyclase activities and cyclic nucleotide values. Thus, 11 samples were used for adenylate cyclase, nine for cAMP, six for guanylate cyclase, and six for cGMP determination in the untreated patients. In treated patients and in controls six samples were used for each index.

\section{BLOOD AND URINE SAMPLES}

Cyclic nucleotide values were measured in the plasma from all 55 patients with coeliac disease and from the 25 normal subjects, and in the urine from 17 patients and 10 normal subjects. Fifteen of the untreated patients were re-evaluated after six and 12 months of gluten free diet. As changes in extracellular cyclic nucleotide concentrations may result from glucagon or atrial natriuretic peptide hypersecretion, 112 plasma values of these two hormones were assayed in 15 normal subjects, 10 untreated, and 10 treated patients with coeliac disease. All subjects were asked not to take any drug during the two days before the 
study. Urine was collected in refrigerated containers over a 24 hour period, starting between 10 and 12 am on the day before blood sampling. At the end of collection, urine volumes were measured and aliquots frozen at $-30^{\circ} \mathrm{C}$ until assayed for cyclic nucleotide and creatinine content.

Venous blood samples were drawn between 8 and $9 \mathrm{am}$, after an overnight fast and at least one hour's bed rest, for routine haematology and serum biochemistry tests and for the specific analyses. The samples were added to tubes which had been chilled previously containing disodium ethylenediaminetetraacetate (EDTA) ( $5 \mathrm{mM}$, final concentration) for cyclic nucleotide assay, and EDTA and aprotinine $(500 \mathrm{KIU} / \mathrm{ml})$ for atrial natriuretic peptide and glucagon assays. Samples of plasma were separated immediately by centrifugation at $4^{\circ} \mathrm{C}$ and stored at $-80^{\circ} \mathrm{C}$ until assayed.

\section{TISSUE PREPARATION}

Biopsy specimens were washed in saline, and homogenised in an ice cold buffer ( $25 \mathrm{mM}$ TRIS $\mathrm{HCl}, \mathrm{pH} \mathrm{7 \cdot 5,} 1 \mathrm{mM}$ EDTA, $1 \mathrm{mM}$ dithiothreitol) using a Teflon glass homogeniser (10 strokes). Cell disruption was checked at microscopy. Protein content was determined by Lowry's method. ${ }^{13}$

INTRACELLULAR CYCLIC NUCLEOTIDE ASSAY Cyclic nucleotides were extracted from homogenates by boiling and sonicating, as previously described, ${ }^{14}$ and their values measured by radioassay (cyclic AMP assay kit, code TRK 432; cyclic GMP RIA kit, code TRK 500, Amersham, Buckinghamshire) in freeze dried $3500 \mathrm{~g}$ supernatants $\left(20\right.$ minutes at $\left.4^{\circ} \mathrm{C}\right)$, reconstituted in water. Protein concentrations were $0.2-1.0 \mathrm{mg} /$ $\mathrm{ml}$ for cAMP and $0.75-1.25 \mathrm{mg} / \mathrm{ml}$ for cGMP determination. Each sample was tested in triplicate. The results were expressed as pmol of cyclic nucleotide/mg of protein.

ADENYLATE AND GUANYLATE CYCLASE ASSAYS Biopsy homogenates were centrifuged at $7000 \mathrm{~g}$ for 15 minutes at $4^{\circ} \mathrm{C}$ and the pellets resuspended in the homogenisation buffer to obtain a protein concentration of $1-4 \mathrm{mg} / \mathrm{ml}$. Adenylate cyclase activity was assayed at $30^{\circ} \mathrm{C}$ for 10 minutes in
$50 \mu \mathrm{l}$ of an incubation mixture containing $25 \mathrm{mM}$ TRIS $\mathrm{HCl}(\mathrm{pH} \mathrm{7.5}), 5 \mathrm{mM} \mathrm{MgCl}_{2}, 0.5 \mathrm{mM}$ ATP, $0.5 \mathrm{mM}$ isobutylmethylxanthine, $5 \mathrm{mM}$ creatine phosphate, creatine phosphokinase (50 $\mathrm{U} / \mathrm{ml}$ ), $1 \mathrm{mM}$ dithiothreitol, bovine serum albumin $(0.1 \mathrm{mg} / \mathrm{ml}), 10 \mu \mathrm{M}$ guanosine triphosphate (GTP), and homogenate (10-40 $\mu \mathrm{g}$ of protein). Incubations were performed under basal conditions, in the presence of $4 \mu \mathrm{M}$ forskolin (a well known stimulator of adenylate cyclase) used to check if the homogenates retained the ability to respond to stimuli and with a peptic tryptic cotazym digest ${ }^{15}$ of bread (San Pastore) wheat gliadin $(50 \mu \mathrm{g} / \mathrm{ml})$ (supplied by $\mathrm{Dr} M \mathrm{De}$ Vincenzi, Istituto Superiore di Sanità, Istituto Sperimentale per la Cerealicoltura, Rome).

In some experiments incubations were also performed with increasing concentrations of peptic tryptic cotazym gliadin digest (10-200 $\mu \mathrm{g} / \mathrm{ml})$. The reaction was stopped by boiling for 3 minutes. The cAMP produced was measured by radioassay. Guanylate cyclase activity was assayed at $32^{\circ} \mathrm{C}$ for 10 minutes in $100 \mu \mathrm{l}$ of an incubation mixture ( $50 \mathrm{mM}$ TRIS $\mathrm{HCl}, \mathrm{pH} 7 \cdot 5$, $1 \mathrm{mM}$ GTP, $1 \mathrm{mM}$ isobutylmethylxanthine, $4 \mathrm{mM} \mathrm{MnCl}_{2}, 3.7 \mathrm{mM}$ creatine phosphate, creatine phosphokinase $(13 \mathrm{U} / \mathrm{ml})$, homogenate $(10-40 \mu \mathrm{g}$ of protein)), and peptic tryptic cotazym gliadin digest $(10-200 \mu \mathrm{g} / \mathrm{ml})$ when appropriate. The reaction was stopped by adding $100 \mu \mathrm{l}$ of $16 \mathrm{mM}$ EDTA in $50 \mathrm{mM}$ TRIS $\mathrm{HCl}$ (pH 7.5), and heating at $90^{\circ} \mathrm{C}$ for 3 minutes. The cGMP produced was measured by radioimmunoassay (RIA).

The formation of both cAMP and cGMP was linear with time for at least 15 minutes, and with protein concentration. All the enzyme assays were run in triplicate. Results were expressed as pmol of cyclic nucleotides produced for 10 minutes/mg of protein.

EXTRACELLULAR CYCLIC NUCLEOTIDE ASSAY Urine was diluted 25 to 100 times with TRISEDTA buffer ( $50 \mathrm{mM}$ TRIS $\mathrm{HCl}, 4 \mathrm{mM}$ EDTA, $\mathrm{pH} 7.5$ ) before being assayed for cyclic nucleotides. Plasma was extracted with ethanol as previously described. ${ }^{16}$ All samples were tested in triplicate using at least two different dilutions. Results were expressed as $\mathrm{pmol} / \mathrm{ml}$ for plasma and as $\mu \mathrm{mol} / \mathrm{g}$ of creatinine for urine. Nephrogenous CAMP was also calculated by subtracting the filtered fraction (plasma cAMP $\mathrm{x}$ creatinine clearance) from total urinary cAMP.

TABLE I Adenylate and guanylate cyclase activity in duodenal mucosa biopsy homogenates from untreated and treated coeliac disease patients and from control subjects (values mean (SEM))

\begin{tabular}{|c|c|c|c|c|c|c|c|}
\hline & \multicolumn{4}{|c|}{$\begin{array}{l}\text { Adenylate cyclase activity } \\
\text { (pmol cAMP/10 min/mg of protein) }\end{array}$} & \multicolumn{3}{|c|}{$\begin{array}{l}\text { Guanylate cyclase activity } \\
\text { (pmol cGMP/10 min/mg of protein) }\end{array}$} \\
\hline & $\begin{array}{l}\text { Cases } \\
(n)\end{array}$ & Basal & $\begin{array}{l}\text { Forskolin } \\
\left(4 \times 10^{-6} \mathrm{M}\right)\end{array}$ & $\begin{array}{l}\text { PTC gliadin } \\
\text { digest } \\
(50 \mu \mathrm{g} / \mathrm{ml})\end{array}$ & $\begin{array}{l}\text { Cases } \\
(n)\end{array}$ & Basal & $\begin{array}{l}\text { PTC gliadin } \\
\text { digest } \\
(50 \mu \mathrm{g} / \mathrm{ml})\end{array}$ \\
\hline \multirow{3}{*}{$\begin{array}{l}\text { Controls } \\
\text { Coeliac disease patients at } \\
\text { diagnosis } \\
\text { Coeliac disease patients in } \\
\text { remission }\end{array}$} & 6 & $29 \cdot 8(4 \cdot 31)$ & $175 \cdot 5(35 \cdot 24)^{\star}$ & $30 \cdot 7(3 \cdot 89)$ & 6 & $62 \cdot 9(4 \cdot 79)$ & $61 \cdot 2(5 \cdot 42)$ \\
\hline & 11 & $46 \cdot 2(4 \cdot 15) \ddagger$ & $219 \cdot 5(26.90) \dagger$ & $101 \cdot 5(16 \cdot 17) \dagger$ & 6 & $46 \cdot 9(7 \cdot 18)$ & $55 \cdot 9(9 \cdot 60)$ \\
\hline & 6 & $31 \cdot 0(1 \cdot 86)$ & $161 \cdot 7(28 \cdot 72)^{\star}$ & $41 \cdot 1(5 \cdot 84)$ & 6 & $64 \cdot 6(7 \cdot 07)$ & $74 \cdot 3(11 \cdot 70)$ \\
\hline
\end{tabular}

$\star=\mathrm{p}<0.05$ and $\dagger=\mathrm{p}<0.01 v$ basal, Wilcoxon test

$\ddagger=\mathrm{p}<0.05 v$ controls and patients in remission, Kruskal-Wallis followed by Wilcoxon test; PTC=peptic tryptic cotazym. 


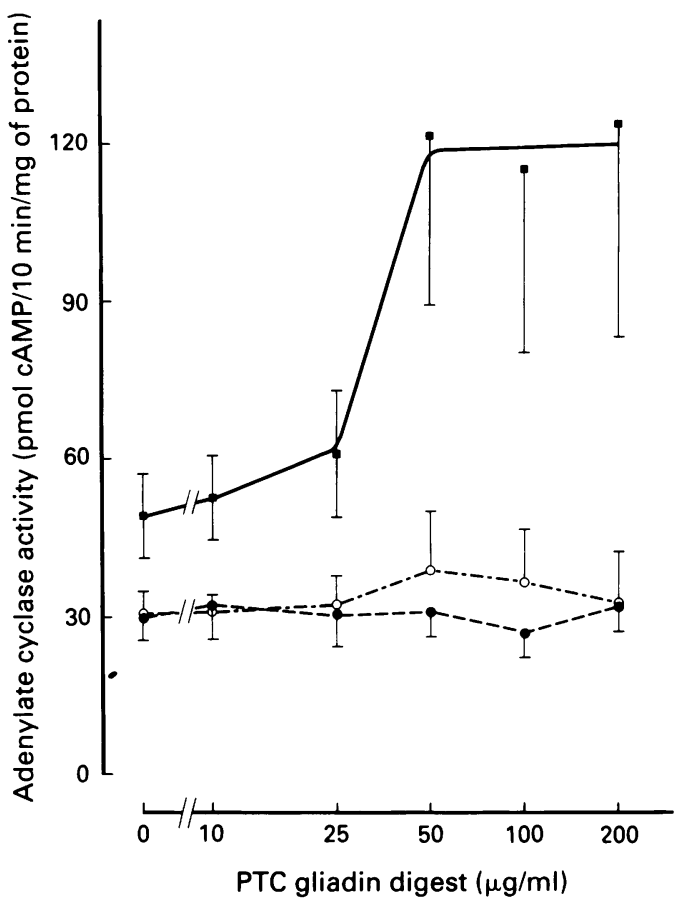

Effect of peptic tryptic cotazym (PTC) gliadin digest on adenylate cyclase activity in duodenal mucosa biopsy specimens from four control subjects $(\mathbf{)})$, five untreated coeliac disease patients $(\mathbf{\square})$, and three treated coeliac disease patients $(\mathrm{O})$.

\section{HORMONE ASSAYS AND BIOCHEMISTRY}

Plasma glucagon and atrial natriuretic peptide values were measured by double antibody RIA methods using commercially available kits (Double Antibody Glucagon, Diagnostic Products Corporation, Los Angeles, CA, USA; Human Atrial Natriuretic Peptide, Immuno Technology Service Production BV, Wijchen, The Netherlands). Plasma atrial natriuretic peptide was extracted according to Sagnella et al. ${ }^{17}$ The lower limits of sensitivity for glucagon and atrial natriuretic peptide assay were $3.7 \mathrm{pmol} / \mathrm{l}$ and $1.1 \mathrm{pmol} / 1$, respectively. The intra and interassay coefficients of variation were $8 \cdot 1$ and $9 \cdot 3 \%$ for glucagon, and 8.4 and $11.3 \%$ for atrial natriuretic peptide. The following analyses were carried out by routine methods: haemoglobin, sodium, potassium, magnesium, calcium, albumin, cholesterol, triglycerides, glucose, iron, folate, and vitamin B12. Carotenemia was measured by a colorimetric method ${ }^{18}$ and antigliadin IgA values by an enzyme immunoassay (Gluten IgA EIA kit, Pharmacia, Upsala, Sweden).

TABLE II Cyclic nucleotide concentrations in duodenal mucosa biopsy homogenates from untreated and treated coeliac disease patients and from control subjects (values mean $(S E M))$

\begin{tabular}{lcl}
\hline & $\begin{array}{l}c A M P \\
(\text { pmol/mg of protein })\end{array}$ & $\begin{array}{l}c G M P \\
(\text { pmol/mg of protein })\end{array}$ \\
\hline $\begin{array}{l}\text { Controls } \\
\begin{array}{l}\text { Coeliac disease patients } \\
\text { at diagnosis }\end{array}\end{array}$ & $7 \cdot 5(1 \cdot 11)(6)^{\star}$ & $1 \cdot 05(0 \cdot 2)(6)^{\star}$ \\
$\begin{array}{l}\text { Coeliac disease patients } \\
\text { in remission }\end{array}$ & $8 \cdot 4(1 \cdot 68) \dagger(9)^{\star}$ & $1 \cdot 60(0 \cdot 07) \dagger(6)^{\star}$ \\
\hline
\end{tabular}

$\star=$ Number of cases; $\uparrow=p<0.05 v$ controls and patients in remission, Kruskal-Wallis test followed by Wilcoxon test.

\section{STATISTICAL ANALYSIS}

Statistical significance of the data was evaluated by one way analysis of variance using Kramer's test for multiple comparison. Nonhomogenously distributed data were analysed by the Kruskal-Wallis and Wilcoxon tests. Linear regression was used for comparison with different variables.

\section{Results}

ADENYLATE AND GUANYLATE CYCLASE ACTIVITIES Under basal conditions adenylate cyclase activity was significantly higher in homogenates of coeliac disease patients who had not been treated than in those of successfully treated patients and of control subjects (Table I). Forskolin stimulated adenylate cyclase activity in all the samples, whereas peptic tryptic cotazym gliadin digest (50 $\mu \mathrm{g} / \mathrm{ml}$ ) significantly increased this activity only in the samples from coeliac disease patients who had not been treated. When the effects of gliadin derived peptides were tested over concentrations ranging from 10 to $200 \mu \mathrm{g} / \mathrm{ml}$, no adenylate cyclase activation occurred in the homogenates from control subjects and in those from coeliac disease patients who had been treated. In homogenates from coeliac disease patients who had not been treated peptide concentrations of 10-25 $\mu \mathrm{g} / \mathrm{ml}$ failed to increase adenylate cyclase activity consistently, whereas concentrations of $50-200 \mu \mathrm{g} / \mathrm{ml}$ all stimulated the enzyme to the same degree (Figure). Basal guanylate cyclase activity was lower in homogenates from coeliac disease patients who had not been treated than in those from patients who had been treated and from control subjects, though the differences were not statistically significant (Table I). Peptic tryptic cotazym gliadin digest at concentrations ranging from 10 to $100 \mu \mathrm{g} / \mathrm{ml}$ did not influence the enzyme activity in any of the samples.

\section{INTRACELLULAR CYCLIC NUCLEOTIDE VALUES}

Both CAMP and CGMP values were significantly higher in duodenal mucosa homogenates from coeliac disease patients who had not been treated than in those from patients who had been treated and from control subjects (Table II).

\section{EXTRACELLULAR CYCLIC NUCLEOTIDE VALUES}

There were no age or sex related differences in cyclic nucleotide values in any group of subjects. Plasma cAMP and cGMP values, nephrogenous cAMP, and total cAMP and cGMP urinary excretion were significantly higher in patients who had not been treated than in normal subjects (Table III). After six months of clinically successful diet nephrogenous cAMP decreased appreciably in most patients, though plasma values and total urinary excretion of both cyclic nucleotides showed only a slight downtrend. All these variables, however, were similar to those of normal subjects in the 15 patients re-evaluated after 12 months of gluten free diet as well as in the 35 patients who were treated for more than one year, who were all in clinical, biochemical, and histological remission. In coeliac disease 
TABLE III Plasma and urine cyclic nucleotide values in untreated and treated coeliac disease patients and in control subjects (values mean $(S E M)$ )

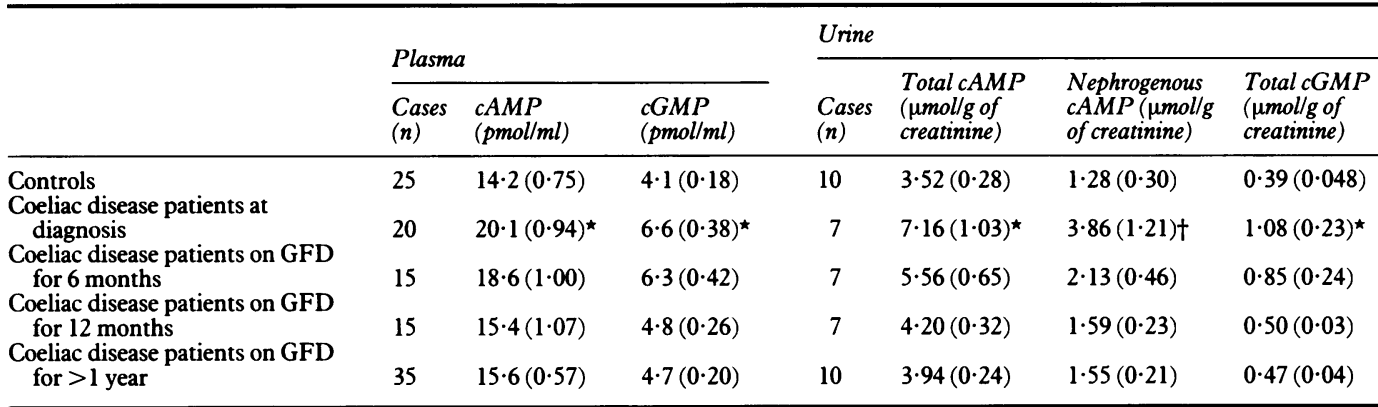

$\star=\mathrm{p}<0.01 v$ controls, GFD 12 months and GFD $>1$ year, Kramer test; $\mathrm{\dagger}=\mathrm{p}<0.01 v$ controls and GFD $>1$ year, $\mathrm{p}<0.05 v$ GFD 6 months and GFD 12 months, Kramer test; GFD=gluten free diet.

TABLE IV Plasma glucagon and atrial natriuretic peptide $(A N P)$ values in untreated and treated coeliac disease patients and in control subjects (values mean (SEM))

\begin{tabular}{llll}
\hline & $\begin{array}{l}\text { Cases } \\
(n)\end{array}$ & $\begin{array}{l}\text { Glucagon } \\
(\text { pmol/l) })\end{array}$ & $\begin{array}{l}\text { ANP } \\
(\text { pmolll })\end{array}$ \\
\hline $\begin{array}{l}\text { Controls } \\
\begin{array}{l}\text { Coeliac disease patients at } \\
\text { diagnosis }\end{array}\end{array}$ & 15 & $24 \cdot 3(2 \cdot 19)$ & $10 \cdot 5(1 \cdot 51)$ \\
$\begin{array}{l}\text { Coeliac disease patients in } \\
\text { remission }\end{array}$ & 10 & $22 \cdot 3(3.47)$ & $11.4(2 \cdot 24)$ \\
\hline
\end{tabular}

patients who had not been treated both total and nephrogenous cAMP urinary excretion were inversely related to serum calcium values $(\mathrm{r}=-0.759, \mathrm{p}<0.05 ; \mathrm{r}=-0.876, \mathrm{p}<0.01)$. No correlations were found in any group of subjects between extracellular cyclic nucleotide values and the other biochemical variables considered, including plasma glucagon and atrial natriuretic peptide values, when measured. No significant differences in mean basal glucagon and atrial natriuretic peptide values were seen among normal subjects and coeliac disease patients who had been treated and those who had not (Table IV).

\section{Discussion}

This study showed that in both duodenal mucosa specimens and extracellular fluids the pattern of cyclic nucleotides was abnormal in patients with active coeliac disease, but similar to that of control subjects in patients successfully treated with a gluten free diet. In small intestinal mucosa homogenates from patients who had not been treated the increased basal adenylate cyclase activity, reported also by others ${ }^{12}$ could in itself account for the presence of high cAMP values. The finding of high cGMP values, however, with a relatively low guanylate cyclase activity could suggest a reduced rate of cGMP degradation. On the other hand, discrepancies between intracellular cGMP values and guanylate cyclase activity in broken cells have often been found in response to hormones and other biologically active substances. ${ }^{19}$ This suggests that some mechanisms modulating cGMP production in whole cells cannot be activated in cell free systems. Intestinal crypt cells are known to have a higher adenylate cyclase and a lower guanylate cyclase activity than differentiated villous cells. ${ }^{20}$
Therefore, changes in the cyclase-cyclic nucleotide systems in the atrophic intestinal mucosa of coeliac disease patients could be related to the immature character of rapidly proliferating enterocytes in the disease. As a result of the cell heterogeneity of biopsy specimens, however, it cannot be excluded that inflammatory cells, widely infiltrating the mucosa of coeliac disease patients who have not been treated, also contribute to the changes of cyclic nucleotide metabolism. Regardless of the cell populations involved, Beguinot $e t a l^{2}$ and our own finding that gliadin derived peptides stimulate adenylate cyclase activity in small intestinal mucosa homogenates from patients who have not been treated suggests a role for cAMP in the pathophysiological processes of coeliac disease. This possibility is also supported by the finding that in active coeliac disease intestinal synthesis and secretion of prostaglandin $\mathrm{E}_{2}$, which stimulates adenylate cyclase activity, ${ }^{3}$ are abnormally high under basal conditions and further increase after a gliadin challenge..$^{21}$ Failure of gliadin derived peptides to activate adenylate cyclase in duodenal biopsy homogenates from patients who have been successfully treated may be ascribed to the repair of mucosal damage.

Our results also showed that plasma and urine cAMP and cGMP values were abnormally high in coeliac disease patients who had not been treated, and became normal only after treatment when clinical, biochemical, and histological remission was achieved. Abnormal hormone secretion in active coeliac disease may have contributed to these changes. The finding that untreated patients with severe hypocalcemia showed the highest values of total and nephrogenous urinary cAMP is in keeping with the notion that a secondary hyperparathyroidism may occur in active coeliac disease. ${ }^{22}$ Hyperparathyroidism does not account, however, for the other changes in extracellular cyclic nucleotide values seen by us. Moreover, our patients showed normal plasma values of glucagon and atrial natriuretic peptides, the only other hormones known to influence extracellular cyclic nucleotide values. ${ }^{112}$ On the other hand, the small intestine is an important source of circulating cyclic nucleotides. ${ }^{1223}$ Therefore, it seems likely that in coeliac disease extracellular cyclic nucleotide concentrations may reflect the 
abnormally high cAMP and cGMP content of mucosa from the small intestine.

In conclusion, this study provides evidence that cyclic nucleotide metabolism is changed in active coeliac disease. The significance of these changes is still unclear, although one could speculate that high values of cAMP, and perhaps of cGMP, in enterocytes contribute to the pathogenesis of diarrhoea. Also the specificity of our results needs to be verified as we did not study patients with other inflammatory bowel diseases.

We are grateful to Dr A Orsatti and Dr E Lorenzano for performing the hormonal assays. This work was in part supported by MPI $60 \%$ grants $12-02-8,12-01-17,12-01-88,12-01-1$.

1 Tripp JH, Manning JA, Muller DPR, Walker-Smith JA, O'Donoghue DP, Kumar PJ, et al. Mucosal adenylate cyclase and sodium-potassium stimulated adenosine triphosphatase in jejunal biopsies of adults and children with coeliac phatase in jejunal biopsies of adults and children with coeliac
disease. In: McNicholl BM, McCarthy CF, Fottrell PF, eds. disease. In: McNicholl BM, McCarthy CF, Fottrell PF, eds.
Perspective in coeliac disease. Lancaster: MTP Press, 1978: Perspective

2 Beguinot L, Auricchio S, Bernardin JE, de Ritis G, De Vincenzi M, Kasarda DD, et al. In vitro activation of adenylate cyclase of atrophic celiac intestinal mucosa by wheat gliadin-derived peptides. Pediatr Res 1986; 20: 42-4.

3 Kimberg DV, Field M, Johnson J, Henderson A, Gershon E. Stimulation of intestinal mucosal adenyl cyclase by cholera enterotoxin and prostaglandins. $\mathcal{F}$ Clin Invest 1971; 50: 1218-30.

4 Walling MW, Mircheff AK, Van Os $\mathrm{CH}$, Wright EM. Subcellular distribution of nucleotide cyclases in rat
intestinal epithelium. Am $\mathcal{F}$ Physiol 1978; 235: E539-45.

5 Field $M$. Role of cyclic nucleotides in enterotoxic diarrhea. ield M. Role of cyclic nucleotides in enter

6 Guarino A, Cohen MB, Giannella RA. Small and large intestinal guanylate cyclase activity in children: effect of age and stimulation by Escherichia coli heat-stable enterotoxin. Pediatr Res 1987; 21: 551-5.

7 Goldberg ND. Editorial comments: cyclic nucleotides and cellular events related to cell growth. Adv Cyclic Nucleotide Res $1980 ; 12$ : 147-50.
8 Bourne HR, Lichtenstein LM, Melmon KL, Henney CV, Weinstein Y, Shearer GM. Modulation of inflammation and immunity by cyclic AMP. Science $1974 ; 184$ : 19-28

9 Parker CW. Editorial comments: modulation of lymphoid cell function and allergic responses. Adv Cyclic Nucleotide Res $1980 ; 12$ : 181-5.

10 Scott BB, Losowsky MS. Patchiness and duodenal-jejunal variation of the mucosal abnormality in coeliac disease and dermatitis hepertiformis. Gut 1976; 17: 984-92.

11 Davies TF, Prudhoe K, Douglas AP. Plasma cyclic adenosine $3^{\prime}, 5^{\prime}$-monophosphate response to glucagon in patients with $3^{\prime}, 5^{\prime}$-monophosphate response to g
liver disease. $B M \mathcal{F} 1976 ; 1: 931-3$.

12 Ito K, Yukimura T, Takenaga T, Yamamoto K, Kangawa K, Matsuo $\mathrm{H}$. Small intestine as possible source of increased plasma cGMP after administration of $\alpha$-hANP to dogs. Am $\mathcal{J}$ Physiol 1988; 254: G814-8.

13 Lowry OH, Rosenbrough NJ, Farr AL, Randall RJ. Protein measurement with the Folin phenol reagent. $\mathcal{F}$ Biol Chem 1951; 193: 265-75.

14 Peracchi M, Maiolo AT, Lombardi L, Catena FB, Polli EE. Patterns of cyclic nucleotides in normal and leukaemic human leucocytes. BrF Cancer 1980; 41: 360-71.

15 de Ritis G, Occorsio P, Auricchio S, Gramenzi F, Morisi G Silano V. Toxicity of wheat flour proteins and proteinderived peptides for in vitro developing intestine from rat fetus. Pediatr Res 1979; 13: 1255-61.

16 Peracchi M, Bamonti Catena F, Lombardi L, Reschini E Toschi V, Maiolo AT, et al. Plasma and urine cyclic Toschi V, Maiolo AT, et al. Plasma and urine cyclic nucleotide levels in patients with hyperthyroidism

17 Sagnella G, Markandu ND, Shore AC, MacGregor GA Effects of changes in dietary sodium intake and saline infusion on immunoreactive atrial natriuretic peptide in human plasma. Lancet 1985; ii: 1208-10.

18 Carr FH, Price EA. Colour reaction attributed to vitamin A. Biochem F 1926; 20: 498-50.

19 Goldberg ND, Haddox MK. Cyclic GMP metabolism and involvement in biological regulation. Annu Rev Biochem 1977; 46: 823-96.

20 Quill H, Weiser MM. Adenylate and guanylate ciclase activities and cellular differentiation in rat small intestine. Gastroenterology 1975; 69: 470-8.

21 Lavo B, Knutson L, Loof L, Hallgren R. Gliadin challengeinduced jejunal prostaglandin $\mathrm{E}_{2}$ secretion in celiac disease. induced jejunal prostaglandin $\mathrm{E}_{2}$

22 Caraceni MP, Molteni N, Bardella MT, Ortolani S, Nogara A, Bianchi PA. Bone and mineral metabolism in adult celiac disease. Am F Gastroenterol 1988; 83: 274-7.

23 Wehmann RE, Blonde L, Steiner AL. Sources of cyclic nucleotides in plasma. $\mathcal{F}$ Clin Invest 1974; 53: 173-9. 